space makes many uneasy and leads to doubts that it is the core concept for the new hierarchical theory of evolution.

I thoroughly enjoyed many parts of the book, for example the long and rewarding chapter on the evolution of development with its strong focus on the positive evolutionary effects of constraints, and the concluding chapter that deals extensively with spandrels. The structuralist message of these chapters is strong and clear, but it is integrated with functionalist and historical perspectives as well. Parallel evolution is given the attention I believe it merits, and Gould does an admirable job of showing why it is important. A fan of Hox genes (he loves the word 'hoxology'), Gould also shows the importance of developmental genetics for his hierarchical perspective and for understanding the evolution of form in organisms.

Gould, the most widely known evolutionist of our time, has remained active in research while at the same time communicating his evolutionary message to the public through his prolific writings and appearances. This book demonstrates that he is not just a popularizer, but a major intellectual force in his discipline. Yet one can predict a strong negative reaction because the book is annoyingly self-congratulatory and selfserving. But what can he do? He is certain that he is right! A strength, and at the same time a weakness, of this book is that the author's powerful personality emerges on nearly every page. The important messages of this book are appreciated most fully when the reader accepts and enjoys the idiosyncrasies of this extraordinary man.

David B. Wake is at the Museum of Vertebrate Zoology, University of California, Berkeley, California 94720-3160, USA.

\section{The nature of nature's economy}

\section{Human Well-Being and the Natural Environment \\ by Partha Dasgupta \\ Oxford University Press: 2001. $£ 25$ \\ The New Economy of Nature: The Quest to Make Conservation Profitable \\ by Gretchen Daily \& Katherine Ellison Island Press: 2002. $£ 19.50$}

\section{Norman Myers}

We overexploit our environments and we underutilize them. We convert forests into newspapers with disregard for their many other outputs such as watershed functions and climate regulation. We drain wetlands for housing to the detriment of their role in flood control and as species habitats. Yet it is the abundant 'ecosystem services' that often

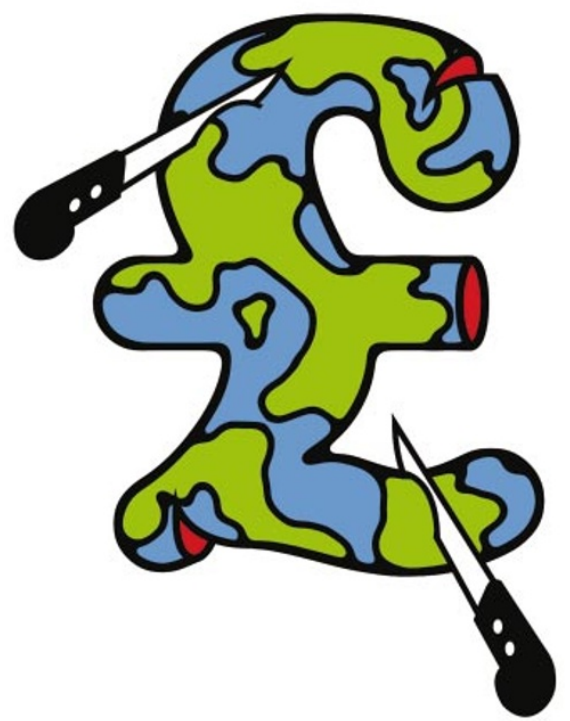

offer more to society than limited products with limited benefits. But everybody's benefits tend to be nobody's business as nobody owns the ecosystems services, so nobody has an incentive to protect them. Everybody's atmosphere becomes everybody's garbage bin for pollutants, and everybody's river becomes everybody's sewer.

Let us welcome, then, these two books, which show us how to get on top of the problem before it gets on top of us. Human Well-Being and the Natural Environment, by a past president of the British and European Economics Associations, focuses on the contributions of ecosystem services to the quality of life, with emphasis on impoverished communities of developing countries. The author is concerned that even though the natural environment is central to our lives, it is "absent from national accounts, from quality-of-life indices, and, more generally, from official development economics". Hence, we "must stop viewing the environment as an amenity, a luxury the poor can't afford". In fact, Dasgupta argues that the environment is often the greatest asset for poor families because they have few alternatives for income if it fails.

The book ranges over such disparate topics as well-being (both personal and social), GNP as a measure of well-being (deeply inaccurate and even misleading as it is), the Human Development Index (the United Nations' measure of social and economic advancement), poverty and consumption, population pressures, technological change, markets and other economic institutions, common property resources, economic efficiency versus social equity, intergenerational conflicts, human rights and civil rights. All are accorded a firm theoretical treatment. The book is solidly interdisciplinary, covering not only economics but ecology, anthropology, political science, philosophy and ethics. It should make a first-rate reader for the World Summit on
Sustainable Development in Johannesburg next August.

While it gives a comprehensive account of what makes up human well-being, the book frequently diverges from certain conventional views. "Countries that would be regarded as having performed well if judged on the basis of such indices as GNP per head or the Human Development Index are found to have grown poorer... the poorest countries have 'developed' by depleting natural capital relative to their high population growth rates." Indeed, Dasgupta deeply disagrees with those many economists who assert that high population growth in poor countries has not slowed their development. Rather, he sees the problem lying with an interactive mix of "high fertility, poverty, malnutrition, illiteracy, and degradation of local natural resource bases, all of which feed on one another cumulatively". Decline of ecosystem services can often serve as a crucial catalyser of deficiencies in other sectors. In other ways, too, the book's message contrasts sharply with much contemporary thinking on economic development.

Parts of the book will prove too dense and technical for those with expertise outside economics. But Dasgupta outlines his theme in an introductory summary, a sort of roadmap for the many analytic pathways ahead. Each of the book's five parts is preceded by a prologue, further enabling the lay reader to grasp the guts of the discussion in short order. Moreover, Dasgupta frequently engages in happy phraseology that leavens the otherwise heavy text. For instance: "The present is the past's future, [and] the future has an unnerving habit of becoming the present." These stylistic flourishes help to make the book more accessible, which is all the more pertinent in that it addresses factors central to the human condition writ large. Indeed, Dasgupta is at pains to talk in terms more general than economicsspeak, and algebra is confined to a set of appendices. For the specialist, there are over 500 references.

The New Economy of Nature demonstrates that ecosystem services, although nobody's business in established practice, can become profitable business for "green gold prospectors". A good number of innovative entrepreneurs, both private and public, are making big money from these services. One well-known example is New York City, which depends for its water on a watershed, the Catskill Mountains, 125 miles away. The water supply could be maintained either through a water-filtration plant costing $\$ 6-8$ billion, plus annual maintenance expenses of \$300-500 million, or through an investment of $\$ 1.5$ billion to restore the watershed. No fewer than 140 American municipalities are now calculating the costs of protecting watersheds compared with the costs of building water-purification 
plants. They thus demonstrate that ecosystems are to be viewed as capital assets, supplying both services and savings.

There are a host of similar initiatives around the world. The authors describe in detail how Australia is tackling its farmland salinity crisis through its Murray-Darling Basin Initiative, which, with an investment of US $\$ 1.4$ billion over the first three years, plus a major tree-planting effort, covers 360,000 square miles and accounts for $40 \%$ of the country's agricultural production. The United States offers cash payments for a range of environmentally supportive farming practices. Similarly, Costa Rica supplies payments to farmers who protect ecosystem assets on their land, with compensation based on the ecosystem services provided. The book presents additional breakthroughs in Vancouver, Adelaide and Rio de Janeiro, as well as broad-scope efforts such as tradeable pollution permits for sulphur and carbon dioxide, and safeguard measures for wild pollinators that support one-third of our food crop harvests. The authors emphasize that there are now hundreds of such enterprises, all showing that conservation need not always cost money, rather, it can save it in huge amounts.

In essence, the strategy counters a basic environmental problem: that goods and services without price are usually viewed as without value. As a result, to cite Richard Sandor, a financial innovator in Chicago who has been devising ways to mass market a number of environmental commodities: "Nature [without prices] becomes like an all-you-can-eat buffet" - and few people don't overeat at a buffet. A further result, as the authors document with illuminating detail, is that the "importance of ecosystem services is often widely appreciated only upon their loss". Fortunately, the green gold entrepreneurs are "establishing a truly new economy of Nature, with focus on the self interest factor that makes the strategy self sustaining". The challenge is to change the rules of the game so as to produce new incentives for environmental protection, readily available through the profit motive.

The two books are exemplary expositions of the environment's role in fostering socio-economic advance as part of human well-being. Each in its way is enlightening from start to finish.

Norman Myers is Honorary Visiting Fellow, Green College, Oxford University, Upper Meadow, Old Road, Oxford OX3 8SZ, UK.

\section{More on the environment}

Cradle to Cradle: Remaking the Way We Make Things

by William McDonough \& Michael Braungart North Point Press, $\$ 25$

Eco-economy: Building an Economy for the Earth by Lester R. Brown

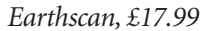

State of the World 2002

by The Worldwatch Institute

Earthscan, £12.95 (UK); W. W. Norton $\$ 29.95$

(hbk), \$15.95 (pbk) (US)

Guide to Sustainable Development and Environmental Policy

edited by Natalia Mirovitskaya \& William

Ascher

Duke University Press, $\$ 89.95$ (hbk), \$34.95 (pbk)

\section{Building machines more like humans}

\section{Flesh and Machines: How Robots Will Change Us \\ by Rodney A. Brooks \\ Pantheon: 2002. 288 pp. \$26}

The Body Electric: An Anatomy of the New Bionic Senses

by James Geary

Weidenfeld \& Nicolson: 2002. 256 pp. $£ 20$

\section{Igor Aleksander}

As robots are made to be more like humans, and human organs are replaced by mechanical artefacts, will humans cease to be more 'special' than machines? A hurried reading of the dust jackets of these two books may give the false impression that they are illinformed texts written to create fears about advancing bionic aliens mischievously created in frankensteinian laboratories. Actually, nothing could be further from the minds of the authors. Both books cover serious scientific and philosophical issues in the design of humanoid robots and the replacement or supplementation of organs.

Rodney Brooks, an influential robotician from the Massachusetts Institute of Technology, has been building what he calls 'artificial creatures' for some years. In Flesh and Machines he writes autobiographically of his flight from 'representational' artificial intelligence, in which the programmer endows the robot with a full description of its environment so that it might act intelligently. Brooks now takes an alternative 'situated' approach in which the robot is equipped with ways of reacting appropriately to its environment without the burden of referring all its actions to pre-digested models supplied by the programmer. Indeed, one of his early models was an insect-like hexapod called Genghis that reacted to the heat emitted by mammals in its vicinity. Later systems include the celebrated Cog, a waist-up robot that moves its limbs and eyes appropriately in the presence of a human. Another machine, Kismet, responds to humans with appealing facial gestures.

An evident weakness in this approach is that Brooks may need to return to some inner representation to introduce the contemplation that humans use a lot of the time, before reacting to their environments. This does not need to be done through pre-programming but in a brain-like fashion through a rapid evolution of, and learning in, an artificial nervous system. Brooks argues that this is just an elaboration of what he has achieved already, but this remains to be seen.

The book moves from an autobiographical to a predictive style in which visions of

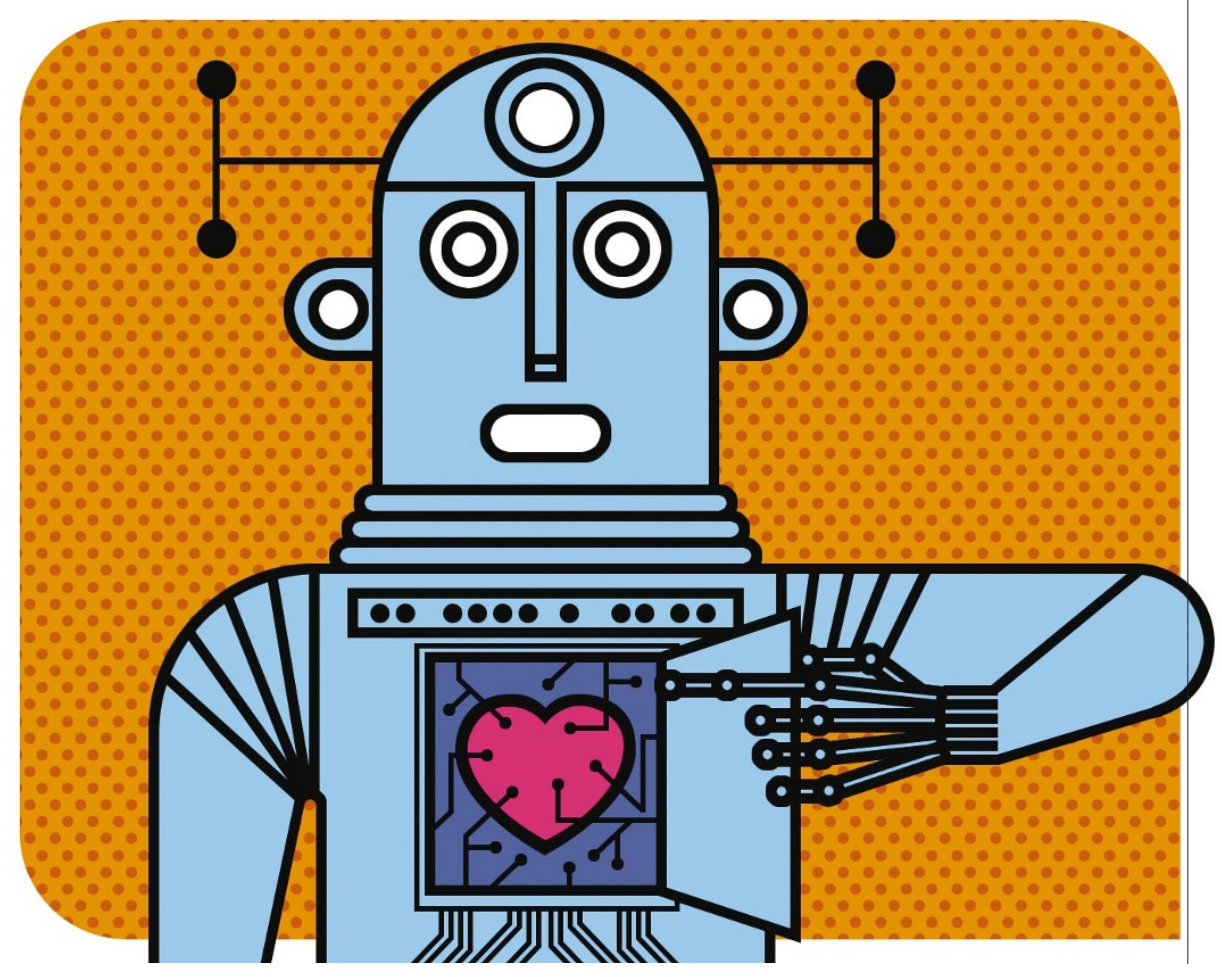

